of those previously acting, namely simultaneous contrast, had alone become valent.

Prof. Halliburton and Dr. Mott made a communication on the effects produced on the arterial blood-pressure by the intravenous injection of choline, neurine, and allied substances. Normal cerebro-spinal fluid produced no effect, while that obtained postmortem from cases of general paralysis of the insane produced a fall of blood-pressure. This is not due to a proteid body present ; for after coagulation by boiling, or precipitation by alcohol, a similar effect is produced. Neurine hydrochloride in $O \cdot I$ per cent. solution gave a similar fall, but in most cases this was followed by a rise and then by a more persistent fall of blood pressure. Choline hydrochloride in 0.2 per cent. solution gave results identical with those obtained by the pathological cerebrospinal fluids. Blood taken from patients suffering from pseudoapoplectiform convulsions of general paralysis was precipitated with alcohol, and the filtrate, after evaporation to dryness and solution in saline, injected, and the effect produced corresponded entirely with that obtained with pathological cerebro-spinal fluids and with solution of choline. Normal blood gave a negative result. The fall of blood-pressure produced by these various reagents is cardiac in origin. This was established by plethysmographic tracings and by experiments on the frog's and mammal's heart. This agrees very well with what is found in general paralysis, cardiac weakness, and enfeebled circulation.

Prof. Richet related experiments by which he had succeeded in showing and measuring in the dog the refractory period of the bulbar and cerebral nervous centres. The animal is cooled down to $30^{\circ} \mathrm{C}$. and anæsthetised. It will then react to electrical stimulations of the cortex if the stimulations be not too frequent. If the rhythm of these be I per second, the responses are equal in magnitude ; if 4 per second, there will be one large and then one small response ; if ro per second, there will be no longer a response to each excitation but one to each alternate. Half of the stimuli fall within a refractory period. The duration of the refractory period is $1 / \mathrm{IO}^{\prime \prime}$. It is possible to show that, as was originally indicated by the experiments of V. Kries, volitional impulses have a frequency of repetition of about 10 or $I I$ in a second.

Dr. F. S. Lee brought forward the results of his continued researches into the functions of the semicircular canals in fishes, especially in regard to maintenance of equilibrium and to locomotion.

Prof. Anderson Stuart made an interesting communication on the canal of Stilling. He also showed models illustrating the horopter.

Mr. O. Grunbaum contributed a communication upon the effects of intermittent retinal stimulation. He exhibited the results of several series of experiments stated in curves with measures of speed of alternation as ordinate-heights and degrees of illumination as abscissæ. The curves so obtained possess each an apex above, denoting that a sensation of continuous stimulation results if the luminosity be below or beyond a certain amount. The curve begins to descend some distance prior to the use of a degree of luminosity such as to produce a blinding after-image.

Dr. A. Grunbaum gave a communication on muscle spindles found in human muscles; the communication was illustrated by microphotograms.

Profs. Boyce and Herdman contributed the results of their investigations on "green oysters." They had demonstrated copper in comparatively large quantity in the green leucocytes of the American oyster. The green colour in these oysters is in direct proportion to the copper present. The copper indicates a pathological condition of these American oysters. They were not prepared to state whether copper in the food of the oyster can bring about the condition, but there is abundant evidence to show that it can occur where no copper mines or other evident sources of copper are present. The normal copper of the hremocyanin of the blood, which is probably constantly circulating through the body in minute quantity, may cease to be removed, and so become stored in certain cells in the oyster. The deposition of the copper in the large quantity found appeared to then the result of a degenerative process.

Prof. Boyce communicated a paper by Dr. Warrington (Liverpool). The effects of ischomia on the structural features of nerve-cells were shown to be very marked. Also the effect of cutting off from the anterior coronal cells the afferent impulses usually impinging on them was studied in cases where the posterior roots had been divided. Marked changes were found, which were minutely described. On the other hand, attempts to discover changes in the cells of the oculomitorius and facialis nuclei after section of their nerve-trunks failed to detect any changes.

In experiments of the kind mentioned above, in which changes uniformly resulted, the typical picture of alteration is very charac. teristic ; the cell becomes somewhat enlarged, is stained red, with a small amount of blue chromophitic granules at its periphery, the nucleus remaining well-marked. The changes go on to a further swelling up of the cell, a disappearance of its nucleus, and finally shrinkage and ultimate disappearance. The paper was illustrated by microphotographs. The method of staining of the preparations employed had been the methylene-blue and erythrosin modification of Nissl's stain.

Prof. Macallum made a long and important communication on the structures of the nucleus and body of the cell, and described the views at which he had arrived on this profound and difficult subject.

Prof. Wesley Mills contributed interesting papers on the psychic development of young animals, on the functional development of the cerebral cortex, and on cortical cerebral localisation.

Miss F. Welby contributed an interesting account of observ. ations on the effect of curvesthetic vapours on the cardiac muscle of the frog; her remarks being illustrated by the projection of the graphic records of the experiments.

The morning of Tuesday, August 24, was devoted to a com. bined meeting of the sections Physiology and Botany to discuss the chemistry and structure of the cell. Several members of the section of Chemistry also took part. the opening paper being by Prof. Meldola. Profs. Marshall Ward, Armstrong, Green, Macallum, Remsen, Farmer, and Halliburton, spoke in the discussion.

Prof. Meldola devoted his opening paper to a discussion of the rationale of chemical synthesis of bodies formed by living organisms.

The presidential address by Prof. Foster was given in the large Zoology Theatre of the University; it was very numerously attended. It was a retrospect of the history of physiology since the previous meeting of the British Association at Montreal in I 884 . It was pointed out that the opportunities for studying physiology had grown larger and more facile. "But there is still a larger outcome from the professional chair and physiological laboratory than the training of students. Each post for teaching is no less a post for learning. Among academic duties the making of knowledge is no less a duty than the distributing of it." "Practical expression has been given to this feeling more vigorously in Canada and the United States than in the old country." "Physiology is destined, in consequence of its containing the study of the actions of the brain, to modify the attitude of the physiologist toward the world, and of the world toward the physiologlst. That physiology is, and must always be the basis of the art of healing is a truism, but if a plebiscite limited to instructed, one might almost say scientific, men were taken at the present moment, it would probably enough be found that the most prevalent conception of physiology is that it is something which is in some way an appendage to the art of medicine." But without plunging " "into the deep waters of the relation which body bears to mind, this at least stares us in the face that changes in what we call the body bring about changes in what we call the mind. When we alter the one we alter the other. . . If, as the whole past history of our science leads us to expect, in the coming years a clearer and clearer insight into the nature and conditions of that molecular dance which is to us the material token of nervous action, and a fuller exacter knowledge of the laws which govern the sweep of nervous impulses along fibre and cell, give us wider and directer command over the moulding of the growing nervous mechanism and the maintenance and regulation of the grown one, then assuredly physiology will take its place as a judge of appeal in questions not only of the body, but of the mind; it will raise its voice, not in the hospital and consulting room only, but also in the senate and the school."

\section{ON THE SUMMIT OF MAUNA LOA.}

$D^{\text {R. H. B. GUPPY has contributed to the Pacific Commercial }}$ Advertiser, published at Honolulu, an account of observ. ations made during a three weeks' sojourn upon the summit of Mauna Loa in August last.

The air at first was highly electrified. A red blanket used No. I 462 , VOL. 57 ] 
by Dr. Guppy crackled under his hands at night, and he could trace letters on its surface in phosphorescent hues with his finger-nail as he lay completely enveloped in its folds. The effects of these meteorological conditions soon showed themselves in the cessation of the action of the skin, in severe head. aches and sore-throat; in a tendency to palpitation and dyspnoea, and in sleeplessness, general lassitude and loss of appetite, most of which symptoms were attributed to the great lack of moisture in the air, for when a short spell of damp weather intervened, most of the unpleasant symptoms disappeared. An interesting phenomenon was observed every morning and evening. For about twenty minutes after sunrise and before sunset the shadow of the mountain was thrown back against the sky of the opposite horizon. It seemed as if some artist had been at work on the sky far away, and had painted in the profile of the mountain with a very uncanny blue.

Dr. Guppy's observations on the relative humidity have yet to be worked out, but he remarks that there was occasionally as much as a difference of $20^{\circ}$ between the wet and dry bulb thermometers, the usual difference being $10^{\circ}$ to $15^{\circ}$. The lowest temperature recorded at night was $15^{\circ} \mathrm{F}$, and the ninimun reading was usually below $20^{\circ}$. The average minimum temperature for the period, August 9 to 31 , was $23^{\circ} 5$. The highest temperature of the air in the shade was $61^{\circ} \cdot 2$, the average maximum daily being $53^{\circ} 6$, which places the average difference between the night and day temperature at $30^{\circ}$. This great daily range is about twice what it is at the coast.

\section{State of the Crater.}

In order to familiarise himself with the principal features of the crater, Dr. Guppy adopted the method of making a rough plan of it with a pocket prismatic compass. In some places the lava crust was thin and fragile, and although he never descended further than his waist, there was always in such localities a chance of a sudden descent into a cavern of considerable depth.

IHis descent into the crater was made on the north-west side. It was a tedious operation, and the loose boulders had to be trodden on very carefully, as they are often inclined to roll down and crush the intruder. As soon as Dr. Cuppy reached near the centre of the great pit the clouds began to pour in on all sides over the lips of the crater. In a few minutes he was enveloped in a dense mist, and any further observation was rendered impracticable. During the prevailing dry clear weather with a cloudless sky, "smoke" is only evident in two places in the crater, one near the centre and the other in the southwest corner from the base of a yellowish cliff, where there are apparently extensive deposits of sulphur. When, however, the sky is clouded, and especially when the air is moist, white vapour may be seen arising from the greater part of the surface of the crater. The change is a little startling, the true explanation being that a large amount of the vapour evolved is only visible in cloudy murky weather. It is, therefore. possible that the accuunts of two olsservers may vary greatly as to the crater's condition, and yet no difference in the con dition actually exist. This especially applies to the district on the south and south-west borders of the crater, stretching about a mile to the southward. In cloudy weather white vapour arises from many places in this area. In the bright clear weather that prevails the visitor may see nothing, and even walk unwitlingly over numerous cracks and fissures whence the invisible vapour is being discharged. Dr. Guppy took the temperature of several of these fissures. In those where the vapour was only seen in cloudy wetther the temperature was about $104^{\circ} \mathrm{F}$. When the "smoke" is always visible the temperature is far higher, $160^{\circ} \mathrm{F}$. and over. Many of these cracks and fissures exhibit evidence of having originally given passage to vapours at a very high temperature. The subterranean heat appears now more actively displayed in the district extending a mile to the south of the big crater than in the crater itself. A very large amount of vapour is discharged from the borders of a small crater lying near Pohaku Hanalei, and this is probably the smoke sometimes observed from the Kona coast. It is probable that the next eruption will occur on this, the south south-west slope of the mountain.

\section{Insect Life on the Summit.}

Curiously enough, insects of various descriptions are common on the summit. One species of butterfly common at the coast is not at all infrequent. The butterflies were more often to be found dead than alive, and those flying about were in a halfdrowsy condition and easily caught. There were flies of different kinds, the house-fly and the blue-bottle-fly proving a great nuisance. Besides these there were moths, bees, gnats, and an occasional dead dragon-fly; whilst bugs and other in. sects were collected as they fed upon the bodies of the dead butterflies. These insects were more common when the wind was southerly, and no doubt they had been brought up to this absolutely sterile region by the wind. Evidently most if not all of the butterfies and moths soon die, and probably the other in. sects too. The whole matter is, however, very suggestive, and shows how readily insects (even the parasitical bug) may find their way into the upper air-currents.

\section{PALESTINE EXPLORATION. ${ }^{1}$}

THE object of exploration is to obtain accurate knowledge of a country, its inhabitants, and its extant monuments and texts. That of Palestine has special interest to Christian races and to Jews, as serving to explain more clearly the sacred literature of their faith.

The results of such exploration may be judged by looking back a century to the time of Bayle, Voltaire and Astruc, when what was regarded as advanced scientific work assumed that the Hebrews were a savage race without literature, that history only began to be written about 500 B.C., and that the oldest civilisation was that of China and India. It is now known that the art of writing was practised in Egypt and Chaldea as early as 3000 B.c., that the Canaanites about the time of Joshua had a civilisation equal to that of surrounding nations, as had also the Hebrew kings; while, on the other hand, Chinese civilisation is only traceable to about 800 B. C., and that of India was derived from the later Persians, Arabs and Greeks. These results are due solely to exploration.

The requirements for exploration demand a knowledge not only of Syrian antiquities but of those of neighbouring nations. It is necessary to understand the scripts and languages in use, and to study the original records as well as the art and architecture of various ages and countries. Much of our information is derived from Egyptian and Assyrian records of conquest, as well as from the monuments of Palestine itself. As regards siripts, the earliest alphabetic texts date only from about 900 B.C., but previous to this period we have to deal with the cuneiform, the Egyptian, the Hittite and the Cypriote characters. The explorer must know the history of the cuneiform from $2700 \mathrm{~B} \mathrm{c}$. down to the Greek and Roman age, and the changes which occurred in the forms of some 550 characters originally hieroglyphics, but finally reduced to a rude alphabet by the Persians, and used not only in Babylonia and Assyria but also as early as 1500 B.C. in Asia Minor, Syria, Armenia, Palestine, and even by special scribes in Egypt. He should also be able to read the various Egyptian sciipts-the 400 hieroglyphics of the monuments, the hieratic, or running hand of the papyri, and the later demotic. The Hittite characters are quite distinct, and number at least 130 characters, used in Syria and Asia Minor from I500 B.C., or earlier, down to about 700 B.C. The study of these characters is in its infancy. The syllabary of Cyprus was a character derived from these Hitlite hieroglyphics, and used by the Greeks about 300 в.c. It includes some fifty characters, and was probably the original system whence the Phœnician alphabet was derived. As regards alphabets, the explorer must study the early Phœenician, and the Hebrew, Samaritan and Moabite, with the later Aramean branch of this alphabet, whence square Hebrew is derived. He must also know the Jonian alphabet, whence Greek and Roman characters arose, and the early Arab scripts-Palmyrene, Nabathean and Sabean, whence are derived. the Syriac, Cufic, Arabic and Himyaritic alphabets.

As regards languages, the scholars of the last century had to deal only with Hebrew, Aramaic, Syriac, Coptic and Greek, but as the result of exploration we now deal with the Ancient Egyptian whence Coptic is derived, and with various languages in cuneiform script, including the Akkadian (resembling pure Turkish) and the allied dialects of Susa, Media, Armenia and of the Hittites; the Assyrian, the earliest and most elaborate of Semitic languages; and Aryan tongues, such as the Persian, the Vannic and the Lycian.

The art and archilecture of Western Asia also furnishes much information as to religious ideas, customs, dress and history, including inscribed seals and amulets, early coins and gems. The explorer must also study the remains of Greek, Roman, Arab and Crusader periods, in order to distinguish these from the earlier remains of the Canaanites, Phœnicians, Hebrews, 1 A discourse at the Royal Institution by Lieut. Colonel C. R. Conder.

NO. 1462 , VOL. 57] 